\title{
MODIFIKASI PISAU MESIN PENEPUNG ATC DENGAN GARIS MATA POTONG PADA SUDUT 330 ARAH RADIAL
}

\author{
Encu Saefudin, Marsono, Erik Puji Nugraha \\ Program Studi Teknik Mesin, Fakultas Teknologi Industri, Institut Teknologi Nasional Bandung \\ J1. PHH Mustafa no.23 Bandung \\ encu@itenas.ac.id
}

\begin{abstract}
Abstrak
Karaginan jenis Kappa adalah senyawa hidrokoloid yang diambil dari rumput laut merah jenis Eucheuma Cottoni, yang banyak digunakan dalam industri pengolahan makanan sebagai pengental, penstabil dan pengemulsi. ATC (Alkali Treated Cottonii) kering yang merupakan produk antara untuk mendapatkan SRC (Semi-Refined Carrageenan) harus menjalani proses lanjutan, yaitu pencacahan dan penepungan. Penelitian ini adalah lanjutan dari penelitian yang dilakukan untuk mengembangkan mesin penepung ATC, dimana pada tahap ini difokuskan pada modifikasi pisau penggerus untuk memperoleh hasil penepungan yang lebih halus. Pengujian yang telah dilakukan menunjukkan bahwa modifikasi pisau memberikan hasil yang lebih baik, yaitu mampu mencapai kehalusan tepung sampai 100 mesh. Tetapi kapasitas mesin penepung ini belum cukup memuaskan karena tepung jumlah yang mencapai 100 mesh hanya 9 gram dari input sebanyak 50 gram.
\end{abstract}

Kata kunci: Karaginan, ATC (Alkali Treated Cottoni), SRC (Semi-Refined Carrageenen), mesin penepung.

\begin{abstract}
Kappa carrageenan is a hydrocolloid compound which is extracted from the red seaweed species of Eucheuma Cottoni. Kappa Carrageenen is widely used in the food processing industry as a thickener, stabilizer and emulsifier. ATC (Alkali Treated Cottonii) which is the intermediate product to obtain SRC (Semi Refined Carrageenan) will go through further processing, such as chopping and grinding. This research is a continuation of the research undertaken to develop ATC grinding machines. This research is focused on modifying the geometry of grinding tools to obtain finer powder results than former research. The tests that have been performed shows that the modifications of tool geometry provide better results, which is able to achieve fine powder up to 100 mesh. But the capacity of this grinding machine is not quite satisfactory because the amount of flour reaches 100 mesh is only 9 grams from 50 grams input.
\end{abstract}

Keywords: Carrageenan, ATC (Alkali Treated Cottonii, SRC (Semi-Refined Carrageenan), grinding machine

\section{PENDAHULUAN}

Karaginan kappa adalah senyawa hidrokoloid yang diekstrasi dari rumput laut merah jenis Euchema Cottonii. Karaginan dapat digunakan untuk meningkatkan kestabilan bahan pangan yang berbentuk suspensi, emulsi. Karaginan dapat digunakan sebagai bahan penstabil karena mengandung gugus sulfat yang bermuatan negatif di sepanjang rantai polimer dan bersifat hidrofilik. Karena sifat hidrofiliknya, karaginan dapat mengikat air atau gugus hidroksil lainnya.

Proses pengolahan rumput laut menjadi karaginan dilakukan dengan serangkaian langkah, antara lain adalah proses alkalisasi, netralisasi dan pengeringan dengan hasil yang didapat berupa ATC (Alkali Treated Cottonii) kering. Selanjutnya ATC kering akan dicacah kemudian dilakukan proses penepungan untuk mendapatkan tepung SRC (SemiRefined Carrageenan). SRC dalam bentuk tepung akan menjadi lebih mudah untuk digunakan pada industri makanan [3]

Proses penepungan adalah tahapan terakhir dalam rangkaian proses pengolahan rumput laut Euchema Cottonii menjadi karaginan dalam bentuk tepung SRC. Untuk mendapatkan tepung SRC tentu dibutuhkan mesin penepung. Namun mesin penepung ATC ini cukup sulit untuk didapatkan di di Indonesia. Di sisi lain, industri pengolahan rumput laut menjadi karagenan yang ada di Indonesia masih sangat tertutup sehingga sulit untuk meniru teknologi yang dipakai di industri tersebut.

36 Saefudin, Encu, dkk.; Modifikasi Pisau Mesin Penepung ATC Dengan Garis Mata Potong Pada Sudut 33o Arah Radial 
Dalam rangka memenuhi kebutuhan alat untuk industri pengolahan rumput laut, maka dalam penelitian ini dilakukan pengembangan mesin penepung ATC. Penelitian ini juga merupakan kelanjutan dari penelitian sebelumnya tentang mesin yang sama. dimana mesin tersebut belum mampu memberikan hasil yang diinginkan. Mesin yang telah dibuat hanya mampu menghasilkan tepung yang sangat kasar yang berukuran 1-10 mm, [5].

Untuk mendapatkan hasil yang lebih baik, dilakukan modifikasi pisau penepung ATC untuk diterapkan pada mesin yang sudah ada. Modifikasi dilakukan terutama dalam hal bentuk (geometri) dan dimensi mata potong pisau. Pisau mesin penepung ATC yang baru dibuat dengan garis mata potong berada pada sudut 330 dari arah radial dengan kedalaman (groove) mata potong tidak lebih dari $3 \mathrm{~mm}$. Pisau penggerus (penepung) tidak dibuat dengan material baja perkakas, tetapi dibuat dengan baja karbon karena penelitian ini difokuskan untuk menilai efektifitas dari bentuk dan ukuran mata potong pisau penggerus

\section{METODE PENELITIAN}

1. Pengolahan Rumput Laut Euchema Cottonii

Rumput laut Euchema cottonii adalah jenis rumput laut yang paling banyak dibudidayakan di Indonesia. Rumput laut jenis ini memiliki kandungan karagenan jenis kappa yang sangat dibutuhkan oleh industri pengolahan makanan, sebagai agen pengental, penstabil dan pengemulsi. Karaginan Kappa juga dibutuhkan oleh industri lain, baik sebagai bahan baku utama, maupun sebagai bahan baku tambahan. Karaginan juga digunakan di indsutri farmasi, tekstil, dan industri lainnya

Karaginan yang diperoleh dari olahan rumput laut jenis Euchema Cottonii dapat dibedakan menjadi dua macam, yaitu karagenan murni (Refined Carrageenan) dan karaginan semi-murni (SemiRefined Carrageenan). Perbedaan keduanya terdapat pada kandungan selulosa yang masih terdapat dalam karaginan tersebut. Karaginan dikatakan murni jika didalamnya sudah tidak lagi terdapat selulosa, sedangkan karaginan yang masih mengandung selulosa disebut sebagai karaginan semi-murni

Metode pembuatan SRC (Semi-refined Carrageenan) berbeda dengan pembuatan RC (Refined Carrageenan). SRC dibuat dengan metoda yang lebih sederhana, dimana karaginan tidak dikeluarkan dari selulosa (jaringan kulit) rumput laut, sehingga selulosanya tetap terbawa dalam produk SRC.

Pengolahan rumput laut Euchema Cottonii menjadi tepung karaginan dilakukan dalam beberapa tahap, yaitu proses alkalisasi, netralisasi, pengeringan, pencacahan dan penepungan. ATC (Alkali Treated Cottonii) kering merupakan produkantara yang diperoleh setelah rumput laut Euchema Cottonii melalui proses alkalisasi, netralisasi dan pengeringan. ATC yang telah kering akan dicacah menjadi ukuran yang lebih kecil dan kemudian digerus sampai mendapatkan tepung karaginan (tepung SRC).

\section{Mekanisme Mesin Penepung}

Mesin penepung ATC yang digunakan adalah mesin penepung hasil penelitian sebelumnya. Mesin penepung ini bekerja dengan prinsip discmill atau attrition mill. Skema mesin penepung ATC yang telah dibuat terlihat pada gambar 1

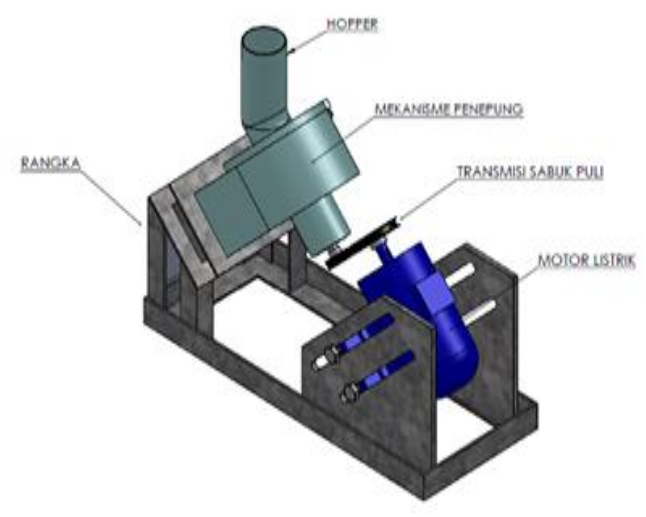

Gambar 1 Skema mesin penepung ATC [1]

Mesin penepung jenis ini mereduksi ukuran partikel padat secara mekanis melalui tumbukan ataupun gesekan antara bahan yang digiling dengan media penggilingan yang kasar. Mekanisme penggilingan pada mesin dihasilkan dari piringan (disc) tunggal yang berputar secara relatif terhadap bidang yang diam ataupun dihasilkan dari piringan ganda yang berputar dengan arah berlawanan.

Pada mesin penepung jenis discmill yang telah dibuat, bahan baku (ATC) masuk dari bagian atas melalui pisau diam dan keluar melalui bagian samping, yaitu melalui celah di antara pisau diam dan pisau gerak setelah mengalami penggerusan, seperti yang terlihat pada gambar 2. Bahan baku ATC yang telah tergerus akan terdorong ke arah luar karena adanya gaya berat dan gaya sentrifigal. 


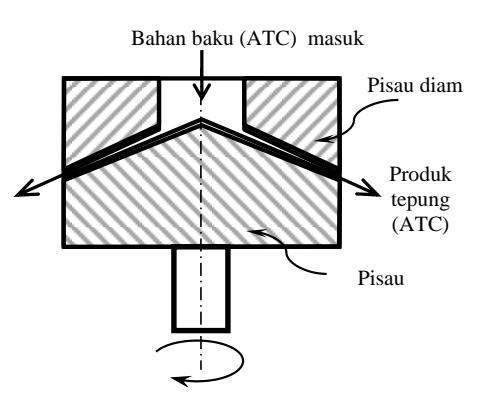

Gambar 2 Aliran masuk bahan baku (ATC) dan keluar produk (tepung) pada mesin penepung

\section{Rancangan Pisau Penggerus}

Rancangan pisau gerak dan pisau diam pada mesin penepung generasi pertama memiliki mata potong yang besar dan jarang. Ketinggian mata potong pisau (kedalaman serasi) lebih dari $3 \mathrm{~mm}$. Rancangan pisau diam dan pisau gerak mesin generasi pertama terlihat pada gambar 3a dan gambar 3b. Permukaan kerucut pada kedua pisau dibagi menjadi delapan segmen dengan adanya alur pada arah radial. Hal ini dilakukan untuk mempermudah proses pembuatan mata potong [1].

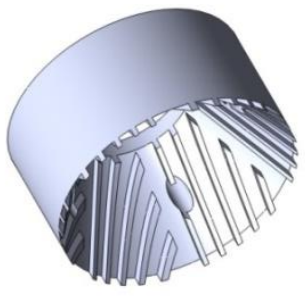

a. Pisau diam

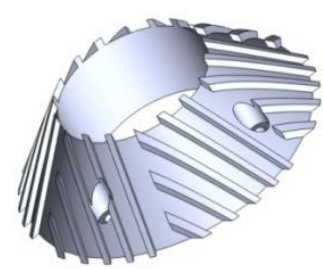

b. Pisau gerak

\section{Gambar 3 Pisau gerak dan pisau diam pada mesin penepung ATC generasi pertama [1]}

Pada penelitaian lanjutannya, pisau gerak dan pisau diam memiliki mata potong yang lebih kecil dan lebih rapat. Ketinggian mata potong (kedalaman serasi) lebih besar dari $3 \mathrm{~mm}$. Permukaan kerucut pada kedua pisau ini juga dibagi menjadi delapan segmen dengan membuat alur pada arah radial untuk memudahkan proses pembuatan mata potong [3]. Rancangan pisau diam dan pisau gerak mesin generasi kedua terlibat pada gambar $4 \mathrm{a}$ dan $4 \mathrm{~b}$

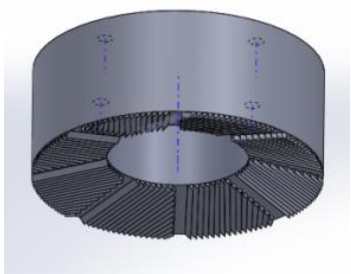

a. Pisau diam

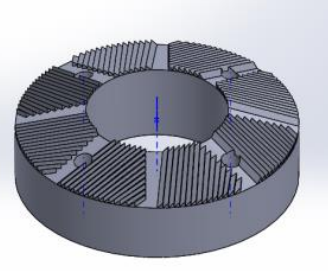

b. Pisau gerak

\section{Gambar 4 Pisau gerak dan pisau diam pada mesin penepung ATC generasi kedua [3]}

Rancangan pisau pada mesin generasi pertama dan kedua masih jauh dari harapan. Rancangan pisau yang telah dibuat hanya dapat menghasilkan tepung yang sangat kasar, yaitu berukuran 1-10 mm [2], [5]. Hasil penepungan dari pisau pada penelitian pertama dan kedua terlihat pada gambar 5.

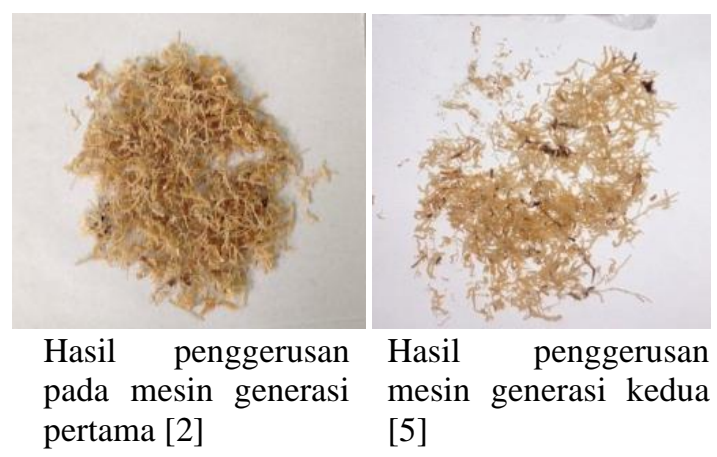

\section{Gambar 5 Hasil pengujian pada penelitian terdahulu}

Berdasarkan hasil dari kedua penelian itu, pada penelitan ini pisau diam dan pisau putar dibuat dengan mata potong yang lebih kecil dan rapat. Disamping itu, ketinggian mata potong pisau sisi masuk (diameter dalam) dibuat lebih tinggi daripada ketinggian mata potong pisau dibagian keluar produk (diameter luar). Ketinggain mata potong pada sisi masuk pisau dibuat $3 \mathrm{~mm}$ sedangkan pada sisi keluar pisau dibuat $2 \mathrm{~mm}$. Garis mata potong berada pada sudut 33o terhadap arah radial. Rancangan pisau diam dan pisau gerak terlihat pada gambar 6 dan gambar 7 .

4. Pembuatan dan perakitan mata pisau diam dan gerak

Pembuatan pisau gerak dan pisau diam dilakukan dengan proses pemesinan dengan menggunakan mesin bubut, frais, dan gurdi. Pisau diam dan pisau gerak yang telah selesai terlihat pada gambar 8(a) dan 8(b) 


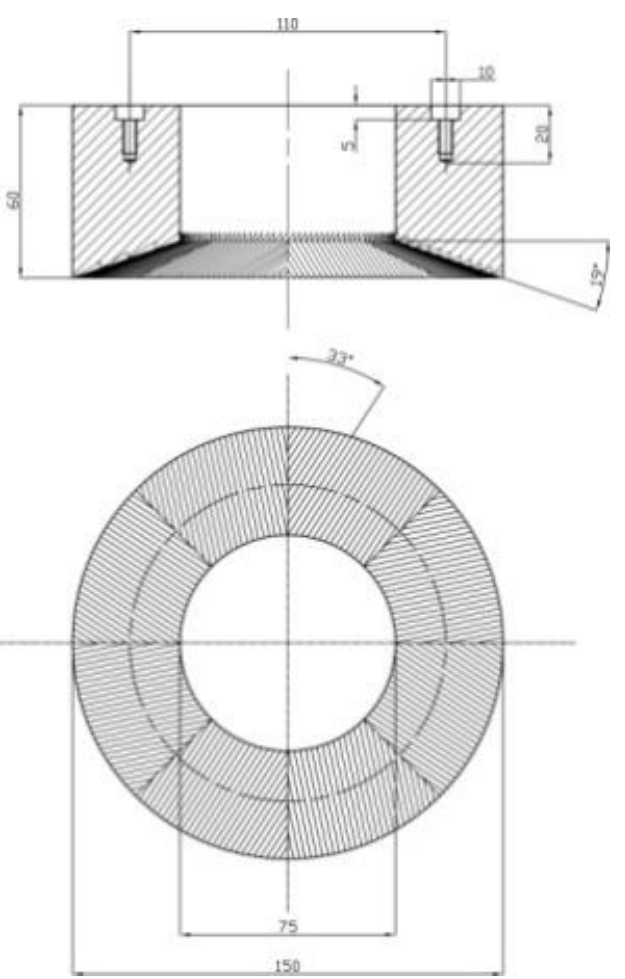

\section{Gambar 6 Rancangan Pisau Diam}
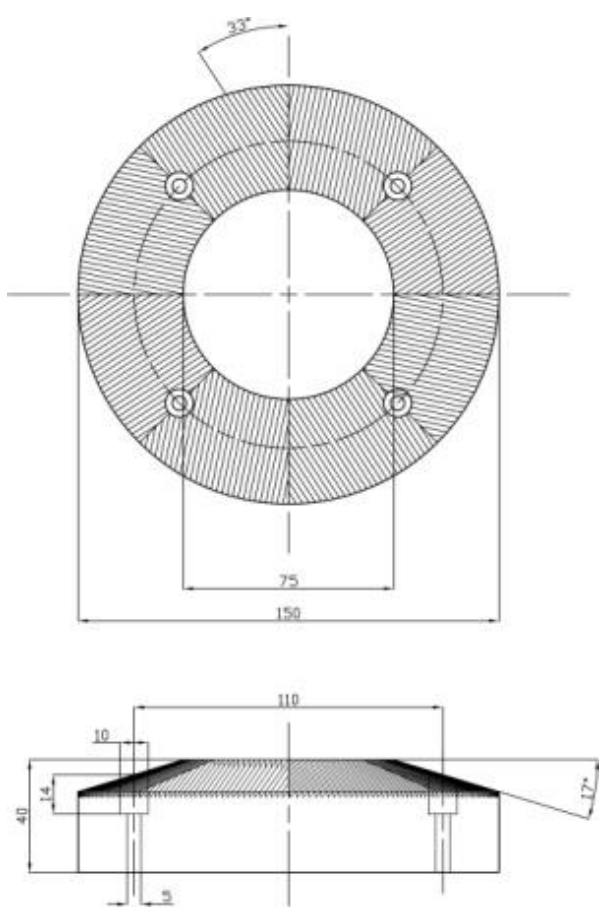

Gambar 7 Rancangan Pisau gerak

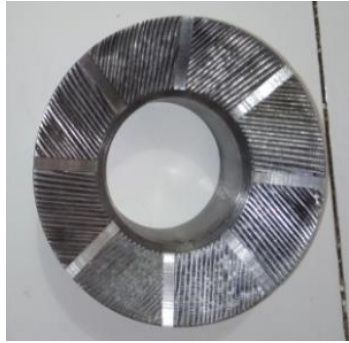

(a) pisau diam

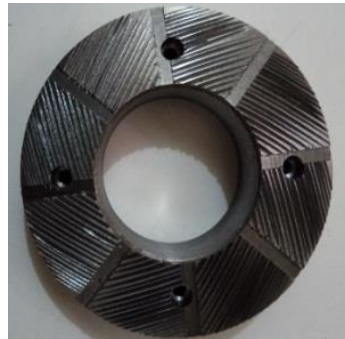

(b) pisau gerak

\section{Gambar 8 Pisau yang telah selesai dibuat}

Setelah selesai dibuat, pisau diam dipasang pada casing yang terhubung dengan hopper dan pisau gerak dipasang pada poros utama yang terhubung dengan motor melalui puli dan sabuk. Proses perakitan pisau pada mesin penepung ATC terlihat pada gambar 9(a) dan 9(b)

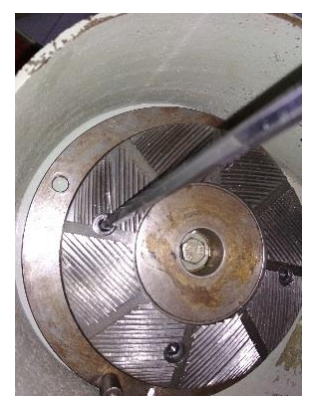

(a) pemasangan pisau gerak pada poros utama penepung

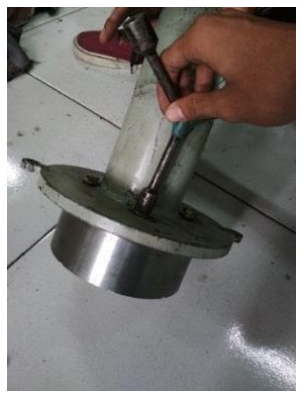

(b) pemasangan pisau diam pada casing mesin penepung

\section{Gambar 9 Pemasangan pisau gerak dan pisau diam pada mesin penepung}

\section{HASIL DAN PEMBAHASAN}

Pengujian dilakukan untuk mengetahui kinerja mesin penepung ATC, khususnya dengan modifikasi pisau dengan geometri mata potong yang lebih kecil dan rapat. Parameter kinerja yang ingin diketahui adalah kehalusan tepung yang dihasilkan dan kecepatan penggerusan. Pengujian dilakukan beberapa kali dengan variasi masukan awal, yaitu 20 gram dan 50gram. Pengujian dilakukan dengan putaran mesin maksimal, yaitu $2445 \mathrm{rpm}$.

Berdasarkan kondisi proses penggerusan yang ditemui pada saat pengujian, dilakukan sedikit perubahan pada prosedur pengujian, yaitu proses pemasukan ATC kering ke dalam mesin dilakukan berulang. Keluaran dari mesin penepung ATC yang 
masih kasar dimasukkan kembali ke dalam mesin penepung untuk digerus kembali.

Tabel 1 Hasil pengujian dengan berat masukan awal ATC 20 gram

\begin{tabular}{llll}
\hline No & $\begin{array}{l}\text { Berat } \\
\text { Awal } \\
(\text { gr })\end{array}$ & $\begin{array}{l}\text { Keluaran } \\
\text { (ATC } \\
\text { tergerus) } \\
(\text { gr) }\end{array}$ & $\begin{array}{l}\text { Waktu } \\
\text { (menit) }\end{array}$ \\
\hline \hline 1 & 20 & 20 & 6,00 \\
\hline 2 & 19 & 1 & 5,00 \\
\hline 3 & 19 & 1 & 5,00 \\
\hline 4 & 19 & 2 & 4,00 \\
\hline 5 & 18 & 2 & 3,30 \\
\hline 6 & 16 & 4 & 6,19 \\
\hline 7 & 14 & 6 & 5,47 \\
\hline 8 & 13 & 7 & 5,12 \\
\hline 9 & 13 & 7 & 4,40 \\
\hline 10 & 11 & 9 & 4,10 \\
\hline 11 & 11 & 9 & 4,00 \\
\hline 12 & 10 & 10 & 3,40 \\
\hline 13 & 10 & 10 & 3,00 \\
\hline 14 & 9 & 11 & 3,00 \\
\hline 15 & 9 & 11 & 3,00 \\
\hline \hline
\end{tabular}

Tabel 2 Hasil pengujian dengan berat masukan awal ATC 50 gram

\begin{tabular}{llll}
\hline No & $\begin{array}{l}\text { Berat ATC } \\
\text { Awal } \\
\text { (gr) }\end{array}$ & $\begin{array}{l}\text { Keluaran } \\
\text { (ATC } \\
\text { tergerus) } \\
\text { (gr) }\end{array}$ & $\begin{array}{l}\text { Waktu } \\
\text { (menit) }\end{array}$ \\
\hline \hline 1 & 50 & 7 & 10,00 \\
\hline 2 & 43 & 7 & 7,45 \\
\hline 3 & 43 & 7 & 5,00 \\
\hline 4 & 41 & 9 & 5,00 \\
\hline 5 & 41 & 9 & 3,35 \\
\hline 6 & 41 & 9 & 3,40 \\
\hline 7 & 38 & 12 & 2,30 \\
\hline 8 & 38 & 12 & 2,30 \\
\hline 9 & 38 & 12 & 5,30 \\
\hline 10 & 36 & 14 & 5,00 \\
\hline 11 & 36 & 14 & 5,30 \\
\hline 12 & 36 & 14 & 5,00 \\
\hline 13 & 33 & 17 & 5,30 \\
\hline 14 & 33 & 17 & 4,48 \\
\hline 15 & 33 & 17 & 2,00 \\
\hline \hline
\end{tabular}

Total waktu: 73 menit 18 detik

Pada kedua pengujian, yaitu dengan pemasukan awal 20gram dan 50gram, pengggerusan dihentikan setelah melewati (pengulangan) sebanyak 15 kali, karena ATC yang tergerus tidak bertambah. Keluaran hasil penggerusan dan waktu penggerusan pada pengujian dengan masukan awal 20gram dan 50gram dapat dilihat pada tabel 1 dan 2.

Hasil penggerusan ini kemudian diayak dengan untuk mengetahui kehalusan tepung dan berat dari masing-masing tepung dengan kehalusan yang berbeda. Hasil dari proses pengayakan untuk masukan awal 20 gram dan 50 gram dpat dapat dilihat pada tabel 3

\section{Tabel 3 Hasil pengayakan keluaran ATC dari} mesin penepung

\begin{tabular}{llll}
\hline \multirow{2}{*}{ Mesh } & \multicolumn{4}{l}{ ATC yang diperoleh (gr) } & \\
\cline { 2 - 4 } & $\begin{array}{l}\text { Masukan } \\
\text { 20gram }\end{array}$ & $\begin{array}{l}\text { Masukan } \\
\text { 50gram }\end{array}$ & awal \\
\hline 8 & 1 & 1 & \\
\hline 16 & 5 & 21 & \\
\hline 30 & 7 & 10 \\
\hline 50 & 3 & 5 \\
\hline 100 & 2 & 6 \\
\hline 200 & 2 & 3 \\
\hline
\end{tabular}

Pengujian yang dilakukan pada mesin penepung ATC yang telah dimodifikasi memperlihatkan hasil penggerusan yang lebih baik daripada hasil penggerusan dari mesin penepung ATC generasi pertama dan kedua. Perbandingan ketiga mesin tersebut terlihat dengan jelas pada gambar 5, gambar 10 dan gambar 11

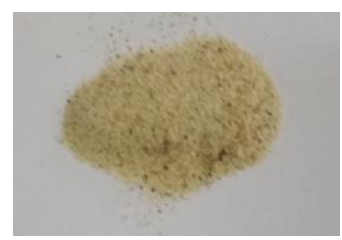

a. 100 mesh (2gram)

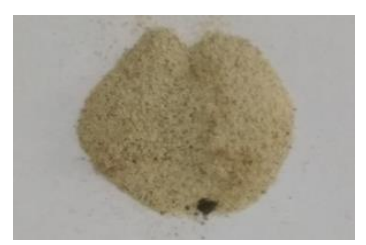

b. 200 mesh (2gram)

\section{Gambar 10 Hasil pengujian dengan berat awal $20 \mathrm{gr}$.}

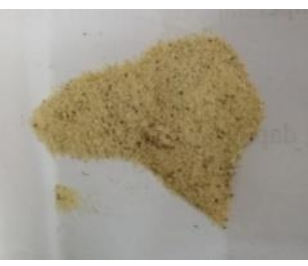

a. 100 mesh (6gram)

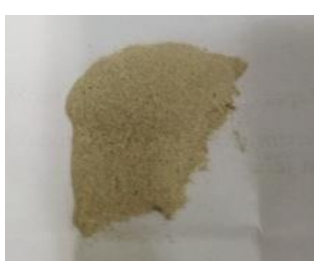

b. 200 mesh (3gram)

\section{Gambar 11 Hasil pengujian dengan berat awal $50 \mathrm{gr}$.}

Pada penelitian sebelumnya, yaitu pada mesin generasi pertama dan kedua didapat hasil yang sangat kasar. Dari mesin generasi pertama didapat 
hasil potongan ATC berukuran $\pm 1-1,5 \mathrm{~cm}$ [2], sama sekali tidak didapatkan tepung. Dari mesin generasi kedua didapatkan tepung sangat kasar dengan ukuran \pm 1-10 mm, [5]. Pada penelitian terakhir ini didapatkan hasil yang lebih baik, yaitu pada pengujian dengan berat awal 20gram dan 50 gram didapat hasil gerusan ATC mencapai 100 mesh dan 200 mesh, walaupun belum semua masuk dalam kategori 100 mesh dan 200 mesh.

Target yang ingin dicapai dari penggerusan mesin penepung ATC ini adalah tepung dengan kehalusan maksimum 100mesh, yaitu sesuai dengan kebutuhan umum di pasaran karaginan. Oleh karena itu, hasil yang dianggap memenuhi target adalah tepung dengan kehalusan maksimum 100mesh.

Hasil yang ada pada tabel 3 menunjukkan bahwa penyaringan dengan menggunakan sieve shaker, didapatkan hasil 2gram ATC dengan kehalusan 100mesh dan 2gram ATC dengan kehalusan 200mesh untuk masukan awal 20gram. Sedangkan untuk masukan awal 50 gram didapatkan hasil 6gram ATC dengan kehalusan 100 mesh dan 3 gram ATC dengan kehalusan 200 mesh.

Kapasitas produksi pada kondisi pengujian ini dapat dihitung dengan membagi berat hasil produk yang memenuhi syarat dengan waktu yang diperlukan untuk mendapatkan hasil tersebut. Maka pada pengujian mesin dengan masukan awal sebesar 20 gram diperoleh kapasitas produksi mesin sebesar $0,060 \mathrm{gram} / \mathrm{menit}$ atau $0,0036 \mathrm{~kg} / \mathrm{jam}$. Untuk pengujian mesin dengan masukan awal sebesar 50gram, didapatkan kapasitas produksi mesin sebesar $0,123 \mathrm{gram} / \mathrm{menit}$ atau $0,0074 \mathrm{~kg} / \mathrm{jam}$.

Modifikasi pisau pada mesin penepung ATC ini memberikan hasil yang cukup memuaskan dalam hal pencapaian kehalusan tepung, namun masiih jauh dari memuaskan jika dilihat dari sisi kapasitas produksinya. Jika dilihat dari sisi efisiensi mesin pun mesin ini masih jauh dari harapan. Efisiensi mesin rata-rata, yaitu penghasilan tepung yang mencapai 100mesh hanya $20 \%$ saja, sedangkan sisanya sebanyak $80 \%$ ATC masih belum tergerus dan menjadi tepung.

Hasil yang belum memuaskan ini tidak bisa terlepas dari dua hal penting, yaitu kesempurnaan atau ketelitian bentuk geometri pisau dan dimensi mata potongnya. Geometri dan dimensi mata potong pisau ini sangat sulit dicapai dengan proses pemesinan konvensional yang dilakukan dengan mesin bubut dan mesin freis. Tidak mudah membentuk geometri pisau dengan garis mata potong membentuk sudut tertentu terhadap arah radial pada bidang selubung kerucut. Garis mata potong pisau seperti ini bukanlah garis lurus melainkan garis yang melengkung. Kesulitan pembuatan pisau ini menjadikan geometri mata potong pisau diam dan pisau gerak tidak terbentuk dengan sempurna, yang tentunya berdampak kepada penurunan efektifitas penggerusan (penepungan).

Di sisi lain, kesalahan atau ketidaksempurnaan geometri dan dimensi mata potong pisau juga ikut menentukan ketelitian celah yang terbentuk di antara pisau diam dan pisau gerak. Geometri pisau yang tidak sempurna akan mengubah ketelitian permukaan selubung kerucut pada kedua pisau dan hal ini akan berdampak kepada ketidakseragaman lebar celah di antara pasangan pisau diam dan pisau gerak pada jarak radius yang sama. Di satu bagian mungkin terbentuk celah yang lebih sempit, sementara di bagian lain pada radius yang sama mungkin terbentuk celah yang lebih lebar.

Konsentrisitas dari kedua pisau juga menjadi masalah tersendiri. Jika pisau diam tidak berada pada sumbu yang sama dengan sumbu pisau gerak maka celah yang terbentuk di antara pisau diam dan pisau gerak tidak akan seragam pada jarak radius yang sama. Hal ni juga akan berdampak kepada penurunan efektifitas penepungan.

Dalam penelitian ini, faktor-faktor seperti akurasi bentuk geometri, dimensi mata potong serta konsentrisitas pisau diam dan pisau gerak membuat celah di antara pisau diam dan pisau gerak tidak bisa lebih sempit dari $1,8 \mathrm{~mm}$. jadi sangat mungkin jika faktor-faktor tersebut menjadi penyebab mengapa sebagian besar ATC kering keluar dari celah penggerusan tanpa tergerus seluruhnya dan tidak dapat mencapai efisiensi penggerusan yang baik.

\section{KESIMPULAN}

Mesin penepung ATC harus dibuat dengan tingkat ketelitian yang cukup tinggi. Kesalahan atau ketidaksempurnaan pada pembuatan pisau diam dan pisau putar akan berdampak kepada lebar celah di antara pisau diam dan pisau gerak menjadi terlalu besar dan tidak seragam. Celah yang terlalu lebar di antara pasangan pisau diam dan pisau gerak akan berakibat pada rendahnya efektifitas dan efisieni proses penepungan.

Kesalahan geometri dan dimensi pada pisau diam dan pisau gerak juga bisa berdampak kepada kesulitan penyetingan celah di antara kedua pisau dan kesalahan kesesumbuan pada kedua pisau. Hal ini juga akan berakibat kepada rendahnya efektifitas dan efisiensi penepungan

Dari pengujian yang telah dilakukan diketahui bahwa modifikasi pisau pada mesin penepung ATC ini sudah berhasil mencapai target kehalusan 100 mesh, walaupun hanya 20\% yang berhasil mencapai kehalusan maksimum 100mesh. Kapasitas penepungan dari mesin dengan modifikasi 
pisau ini mencapai $0,0036 \mathrm{~kg} / \mathrm{jam}$ untuk pemasukan 20 gram dan $0,0074 \mathrm{~kg} / \mathrm{jam}$ untuk pemasukan $50 \mathrm{gram}$.

\section{DAFTAR PUSTAKA}

[1] Encu Saefudin, Marsono, Wahyu (2016) "Perancangan Mesin Penepung Rumput Laut Skala Laboratorium", Prosiding Seminar Nasional Aplikasi Sains \& Teknologi (SNAST), Yogyakarta, 26 November 2016, ISSN: $1979-$ 911X / eISSN: 2541 - 528X, hal 477-484

[2] Haefi. (2016). "Pembuatan dan Pengujian Mesin Penepung Rumput Laut”. Institut Teknologi
Nasional, Bandung. Tugas Akhir Program Strata 1 Teknik Mesin.

[3] Ryan Panji Pratama. (2017). "Perancangan dan Analisis Kekuatan pada Modifikasi Pisau Mesin Penepung Rumput Laut". Institut Teknologi Nasional, Bandung. Tugas Akhir Program Strata 1

[4] Zakka Qays Haniff. (2017). "Pembuatan Modifikasi Mata Pisau Mesin Penepung Rumput Laut" Institut Teknologi Nasional, Bandung. Tugas Akhir Program Strata 1

[5] Dimas Herlambang. (2017) "Pengujian Mesin Penepung Rumput Laut". Institut Teknologi Nasional, Bandung. Tugas Akhir Program Strata 1. 